\title{
Divergency of Emotion in the Perspective of Neuro-sciences and Islam
}

\author{
Puspa Handayani, M. Ansya Al-Asrori, Nur Halimah, Malikhatun \\ Natiqoh, Wildan Alim \\ Universitas Ahmad Dahlan. \\ Puspahandayani28@gmail.com
}

\begin{abstract}
Since the emergence of the symptoms neuroscience in our body the center is in the brain, one of them is emotion. Emotions are intense feelings directed at someone or something, there are differences in studying emotions according to Islamic religion and neuroscience. In neuroscience emotions lie within the limbic system of the brain, whereas in Islamic religion emotions lie in the heart (Qolb). Therefore there are significant differences regarding the emergence of emotions in the neuroscience and religion of Islam, for that we try to correlate with the perspective of the neuroscience and Islam so as to produce an interconnected perspective between the two.
\end{abstract}

Keywords: neuroscience, qolb, emotion

\section{Introduction}

In his book entitled "Theories of Early Childhood Learning in Neuroscience Studies" Suyadi explained that etymology neuroscience is a neural (neural science) study of the nervous system, especially studying neurons or nerve cells with a multidisciplinary approach. While in terminology neuroscience is a field of science specializing in scientific studies of the nervous system. On this basis neuroscience is also referred to as the study of the brain and all the functions of the back nerves. Whereas according to Sarlito W.Sarwono in his book about introductory

AJIS : Academic Journal of Islamic Studies vol. 3, no. 2, December 2018

IAIN Curup - Bengkulu | p-ISSN 2580-3174, e-ISSN 2580-3190

Available online: http://journal.staincurup.ac.id/index.php/AJIS 
general psychology explained the definition of emotion. Sarlito wrote that there are many types of emotions. For comparison, in English there are at least more than 500 words to describe emotions (Averill, 1975 in Feldman, 2003) often there is no uniformity in naming certain types of emotions because it depends on many factors, such as visible behavior (for example: crying, laughing), those stimulating emotions (scary objects, praising speech), physiological reactions that arise (heart palpitations or elevated or normal adrenaline), the individual's character themselves (brave, timid), and the local socio-cultural situation (women may be spoiled, men don't cry, etc.).

Therefore, it can be understood that emotions are a very plural concept so that none of the definitions are universally accepted. Sarlito W.sarwono argues that emotion is a complex reaction (positive and negative) of a person's nervous system to stimuli from the outside or from within itself. the definition illustrates that emotions begin with a stimulus, both from the outside (objects, humans, situations, weather) and from within us (blood pressure, hunger, sleepiness, freshness, etc.), on our senses. Furthermore, we (people, individuals) interpret our perceptions of stimuli as something positive (pleasant, interesting) or negative (frightening, wanting to avoid) which we then translate into physiological and motoric responses (palpitations, gaping mouths, standing feathers, red eyes, etc.) and that's when emotions occur.

\section{Emotions in Neuroscience}

In the large dictionary of Indonesian language emotion is a surge of feelings that develops and recedes in a short time (https://kbbi.web.id/emosi). In our own neuroscience, we already know that neuroscience is the study of the brain. If viewed from an emotional perspective in neuroscience, it is certain that this will be related to the brain. In the early days of life, developing emotions are primary emotions. Primary emotions, separate basic emotions 
emerge in the first 6 months of human life (Sigelmen \& Rider, 2018). Postpartum, the baby shows satisfaction with smiling, intense attraction attracted to one object, and distress in the form of sadness, embarrassment, anger and fear.

According to Schore (2016) neurobiology studies show the massive and dramatic development of brain function in the first 18 months of life, which reflects the enormous synaptogenesis that occurred during the infancy period. Specifically, according to Kinney, Brody, Kloman, \& Gilles (1988) in the age period of 7-15 months, it showed a critical phase of the mylenation process and then experienced rapid maturity in the limbic and associated cortex areas.

The maturity of functions and structures in the area of the limbic system and related cortical areas, marks the development of emotional function in infants at the beginning of their lives. Emotional processing involves areas of the cortex and other related areas such as the area of the gyrus, cingulate, insula, so that the prefrontal cortex. Emotional processing, proposed by LeDoux (Kolb \& Wishaw, 2015), begins thoracic sensory which is then delivered to the cortex and amygdala area. The cortex and amygdala areas interact with each other by transforming the cortex area into the hippocampus formation and then returning to the amygdala. Projections from the cortex to the amygdala that also interact with each other, towards releasing hormones through the pituitary groove in the hypothamulus, activating the autonomic nervous system, generating emotional behavior through the brain stem, and stimulating seizures or attention through the basal forebrain.

Similarly, the emotional processing brain circuits proposed by Papaz (Kolb \& Whisaw, 2015) involve the prefontal cortex and cortex associated with sensory. Prefontal cortex leads to the cingulate cortex and from the sensory cortex then is transformed to the cingulated area of the cortex, the formation of the hippocampus and amygdala. The transformation of the cortex prefrontal through 
the cingulate cortex is delivered to the hippocampus and amygdala and then the amygdala transforms into the hippothamulus area which then becomes a response to behavior. The mammillary nucleus of the hippothamulus, is transformed from the hippocampus which then connects to the cingulate cortex through the anterior thamulus. Variants of diverse expression and emotional processing result from complex systems. Because of the adaptive nature of emotions can help humans to maintain their lives. An example is when humans avoid danger and when organizing on purposeful behavior. Basic emotion originates in complex emotions based on basic emotions. Most researchers believe that complex emotions have not fully emerged until the age of 18-24 months, because complex emotions depend on the child's understanding of himself, which typically occurs at the age of 15-18 months (hook, 2015).

According to Fox (Schore, 2016) complex cognitive assessments and coping become central in emotional experience during the final part of the first year of life until the second year of life. This form of emotion at this age is a complex emotion that is a combination of basic emotions, which comes from socio and cultural learning, which can be identified as a form of widespread emotion, and long-term feelings (Gazzaniga, Ivry, \& Mangun, 2015). Feelings of pride, love, jealousy, sadness or guilt include the scope of complex emotions and their development associated with selfawareness of children, along with maturation of cognitive functions and rewards (learning outcomes).

\section{Emotions in Islamic Perspectives}

We often hear that emotions (feelings) are often associated with the heart, indirectly this states that emotions are located in the heart. Because often religious leaders or religious teachers / religious teachers in the delivery of tausiyah. In the Qur'an, a careful description of the various emotions felt by humans is 
expressed, such as fear, anger, love, antipathy, jealousy, shame of embarrassment, regret, and hatred. Every time you hear the word emotion, people tend to interpret limited attitudes and angry behavior. In fact, the scope of emotions is very broad, not only limited to angry attitudes and behavior. People who are amazed include expressions of emotion. Islam is a religion that highly respects human nature as the most perfect creature of God compared to other creatures.

Al-Qur'an Karim has provided direction for humans, in order to control and direct their emotions well. The Qur'an has also given direction so that humans do not need to be afraid of things that are of no use, such as fear of death and poverty. Al-Qur'an explains to humans to direct their emotions such as anger, love, pride, sadness and joy. The Messenger of Allah witnessed to the Muslims to control and direct their emotions well. Allah Almighty grants some basic emotions in human instincts so that they carry out important tasks in their lives.

According to Dr. Muhammad man Uthman Najati in his book Psychology in the Review of the Prophet's Hadith, emotions can help humans make adaptations to maintain their existence and maintain the continuity of human life itself. For example, the emotion of fear, can keep people away from threatening situations. Fear of keeping someone from falling into danger will take some self-rescue initiatives. Another example is angry emotions, can help a person maintain one's existence to fight the danger that threatens him. Angry emotions can help avoid threats directed at him. Emotions of love can help someone to be attracted to each other's opposite sex. Likewise, children of both descendants will be added that are useful for maintaining human survival.

Some emotions can provide benefits to humans if the levels are still at a reasonable level and applied to the right situation. Whereas if the emotional outburst exceeds the line of reasonableness and is spilled in an improper situation, it will even 
backfire for humans themselves. Another example, reasonable fear of taking an exam, can motivate students to take their lessons seriously and encourage them to pass the test responsibly and well. Beyond that, actually the overflow of emotions will be accompanied by changes in physical temperament. If this happens frequently, it is not possible to cause physical illness. For example due to excessive anger, can increase the frequency of heart palpitations faster. In some people, this condition is very prone to causing a heart attack. Likewise, if you are emotional the level of gastric waste production can be greatly reduced or even stopped. This has a negative effect on the digestive tract and the work of the large intestine. Finally it can lead to instability of the digestive tract and can cause injury to the stomach wall. Emotional bursts that often repeat unnaturally can cause various physical ailments. The Messenger of Allāh at had given the wisdom to the Muslims to control and direct their emotions, namely in the following ways: controlling anger; controlling hate; controlling feelings of desires; controlling pride; and control sadness. Thus are some basic emotions in human instinct that Allah has bestowed, so that emotions can be managed as well as possible, so that the manifestation of peace, tranquility, human life both in the world and in the hereafter. When Uthman Najati (1992: 67), also explained that humans face disturbances and insecurities of the soul or emotion when the psychic conflict takes place or the confluence between two human souls is the soul that believes in Allah SWT and the soul which is according to lust. The state of the human soul like this can be described in the story of the son of Prophet Adam namely Qabil who killed his sibling, habil. This story is in the surah al-maidah, 6:27-30.

\section{Emotions in Al-Qu'ran}

Angry are one form of normal and healthy human emotions. Every individual has been angry for various reasons. Although it is a natural and healthy thing, but if it is not controlled or destructive, 
anger has the potential to create new problems, such as workplace problems, in the family, or interpersonal relationships in society. Al-Qur'an is a holy book which is a revelation of Allah SWT, which is intended for humans, personal self and the universe. The Qur'an is a perfect book, containing various aspects of human life, whether it relates to aqeedah, worship, muamalah, or those related to life in general such as politics, law, peace, war, social and economic. In this social life, human beings have a variety of character traits and problems faced, from gentle character to hard character in solving problems. Every human soul experiences various changes and influences, if humans always carry out the commands of Allah SWT, well, they will gain peace in life, on the contrary if humans do not carry out the commands of Allah, they can be classified as losers. As the word of Allah SWT Q.S Al-Asr verses 1-3 which reads:

Based on the information above, it is known that God in this case affirms the form of oath, where humans are always in a state of loss. The meaning of the word Khuzr (loss) is oriented towards anxiety and indecision, therefore this trait is recommended to be prevented by advising each other and being patient. Even humans mentioned in the Koran are creatures that are always closely related to a state of loss except those who have four (4) traits: 1) believers 2) charity 3) intestate to the truth and 4) mutual wisdom in patience. They do and invite kindness to others. Even though he will not back down, he will face the masyaqat and the disaster in carrying out the good deeds. A person who cannot control and direct his soul, and cannot determine his will and reason, will cause anger. When someone is angry, then surely he is no longer able to control his mind and activities or even unable to control his speech, this will lead to uncontrolled actions or maybe something unexpected will happen because it is carried away by emotions. One of the things that needs to be considered is not the man who is dashing the most handsome person on the battlefield, but the man who is dashing is someone who can control himself when angry. 
The nature of anger can issue orders to the body to vent the resentment of the heart by means of reproaches, actions and other forms of resentment depending on the level of anger of one's faith. For this reason, holding back anger is an act of virtue and Allah SWT likes those who do good. In this context anger is issued by conceit hidden in the innermost part of every stubborn person. Among the anger attitudes are jealousy and envy. Pengkalan both in a lump of meat, if he is good, then the whole body is good. If malice, envy, and anger are among the causes that accompany humans to the area of destruction, then how much he desperately needs knowledge of destruction and ugliness to be vigilant against all that, guard it, throw it from the bottom of the heart if it exists and eliminate it.

Circumstances like this, in the Qur'an often found the mention of the nafs. The term nafs in the Qur'an is interpreted as something that is contained in human beings which results in action. The word nafs in Arabic is still general, and it can have various meanings, which are then added to by the term alamar, so that it becomes a nafs al-amarah which means to have a more specific or specific meaning. And what is meant by special meaning here is lust which tends to be things that are ugly or evil. While the word 'lust' in Indonesian is likely to be connotative, ie something negative. Because something that is passionate will lead and lean toward a result that can cause damage and loss both to yourself, others and the environment. Even though lust is actually neutral depending on its use, for example appetite, appetite for learning, appetite for work and so on. Although later, the Qur'an uses the term nafs in it in many places. This indication is seen as stated in the letter of Joseph verse 53 which means as follows:

"And I did not free myself (from mistakes), because Truly that lust always told evil, except the lust who was blessed by my Lord. My Lord is Forgiving, Most Forgiving 
Understanding in the context of the meaning of the letter Yusuf Verse 53, that the word evil is always colored or preceded by an attitude of anger. While the word anger must be prevented by the uterus. Among the qualities of virtue; courage, loyalty, honesty and patience, the position of the womb or generosity occupies a very high position. Although later, the Qur'an distinguishes the nature of generosity which stems on attitudes or anger nafs with certain patterned. The Qur'an has underscored where the true nature of anger is needed, but not always must be centered physically, and this trait sometimes requires effort from the inside when facing challenges; therefore the patient's value becomes a balance after the phase of generosity.

This is in accordance with the word of God in the letter Ibrahim verse 21 which means as follows:

"And all of them (in the land of Mahsyar) will gather before the presence of God, and those who are weak say to the arrogant people:" Indeed, We were your followers. Can you avoid us from the punishment of Allah? just a little? they replied: "If Allah gave instructions to us, surely we can guide you. it's the same for us, do we complain or be patient. sometimes we don't have a place to escape."

An understanding of the meaning of Ibrahim's verse 21 with reference to the word jaza '(complaining), means that it contains the nature of being unable to resist and too quickly being stubborn or impatient. Therefore, the concept of Islam by focusing on generosity in acting and accepting gracefully (syukr) becomes a determinant for giving birth to a balance including paying attention to welfare. In the context of the Qur'an, the nature of anger and following the lust always means an evil deviation which is likely to lead people astray from the right path. Even the Qur'an mentions lust as a form of implementation which is considered contrary to "knowledge", namely that lust is not at all oriented to truth. In other words, that actions which follow lust and anger by 
themselves are said to be actions without being based on knowledge; and the deed is considered to be limited to the fabrication. On this basis, the nature of anger, excessive desire and fanatical passion, the Qur'an affirms as part of those who turn away from the truth or deny the knowledge. Even the mention of the word anger, in the Qur'an is often limited to attitudes and actions themselves. The Qur'an even describes this nature of anger as a behavior that is neither basic nor knowledgeable. Someone who behaves like that is based on the nature of obeying the lust ', with an emphasis on mental and weak knowledge.

Therefore, the Qur'an indicates the nature of anger with a more spiritual-humathic approach through remembrance, patience, relaxation and including mental totality that is ready to accept the truth. For this reason, a more actual understanding of the nature of anger, which is actually needed, is not always physically focused, and this nature sometimes requires effort when facing challenges; therefore the patient's value becomes a balance after the phase of generosity. Thus, the concept of anger is not only limited and binding on literal meaning, but can be articulated to a substantial meaning which means "loss", which leads to error and / or deviation from the truth.

\section{Conclusion}

From the previous discussion we can take the core of the problem that emotion is a reaction to the complex assessment of a person's nervous system against stimuli from the outside or from within him for the gift given by Allah Ta'ala. Thus, if someone has been overcome by anger, then indirectly he has killed his heart because if someone has been contaminated with anger, then all actions and thoughts become out of control. What he thinks is right then he does and what he thinks is wrong, he still does it because emotions do not see everything from various sides but only from one side. Besides that not all emotions are bad because from the 
previous presentation there has been a lot of information that besides the anger it has a bad impact but still has a good impact even if only a little.

\section{Bibliorgaphy}

Suyadi. 2013. Teori Pembelajaran Anak Usia Dini Dalam Kajian

Neurosains. Yogyakarta: PT Remaja Rosdakarya

Achmadi. Manajemen Qalbu dan Pendidikan Islam.

Muhammad, Achmah. 2009. Spiritual Management: Jurnal MD vol.11 no.1

Kholil, Asy'ari M. 2014. Metode Pendidikan Islam:Jurnal Qatruna Vol. 1 No. 1

Masruroh, Anisatul. 2014. Konsep Kecerdasan Emosional Dalam Perspektif

Pendidikan Islam: Jurnal Kajian Pendidikan Islam Vol.6 No.1

Sarwono, Sarlito W. 2009. Pengantar Psikologi Umum. Jakarta: PT Raja Grafindo Persada.

Latief, Umar. 2015. Konsep Amarah Menurut Al-Qur'an:Jurnal Al-bayan vol. 21 no. 32 
114 | AJIS, Vol. 3 No. 2, Des 2018 